\title{
Gaya Kepemimpinan KH. Dede Saepudin dalam Meningkatkan Kinerja Asatidz
}

\author{
Hida Tazkiatul Muktafa ${ }^{1^{*}}$, Uwoh Saepulloh ${ }^{1}$, Moch Fakhruroji $^{2}$ \\ ${ }^{12}$ Jurusan Manajemen Dakwah, Fakultas Dakwah dan Komunikasi, UIN Sunan Gunung Djati, \\ Bandung \\ 3Jurusan Jurnalistik Ilmu komunikasi, Fakultas Dakwah dan Komunikasi, UIN Sunan Gunung \\ Djati, Bandung \\ *Email: bida.tazkiatul@,student.uinsgd.ac.id
}

\begin{abstract}
ABSTRAK
Penelitian ini bertujuan untuk mengetahui bagaimana gaya kepemimpinan $\mathrm{KH}$ Dede Saepudin dalam meningkatkan kinerja Asatidz di Pondok Pesantren AlMua'awanah. Metode penelitian ini menggunakan metode deskriptif Teknik pengumpulan data dalam penelitian ini yaitu melalui observasi, wawancara, dan studi dokumentasi. Adapun analisis data dilakukan melalui penafsiran logika yang dihubungkan dengan konteks Manajemen Dakwah. Hasil penelitian menunjukkan bahwa: Pertama, Gaya Komunikasi KH. Dede Saepudin dalam meningkatkan kinerja asatidz Pondok Pesantren Al-Mu'awanah menggunakan dua gaya komunikasi, yaitu gaya komunikasi satu arah kepada para santri dalam proses belajar mengajar dengan metode sorogan, setoran hafalan dan ceramah.; Kedua, Jenis pemberian motivasi yang digunakan oleh KH. Dede Saepudin kepada para asatidz adalah motivasi positif yang berupa non-materiil berupa dukungan sosial dan psikologis berupa pendekatan face to face dan musyawarah keluarga setiap bulannya.; Ketiga, Proses pengawasan KH. Dede Saepudin terhadap kinerja asatidz dilakukan dengan cara melihat dari segi kehadiran dan peningkatan belajar santri yang akan dibahas dalam musyawarah keluarga setiap bulannya.
\end{abstract}

Kata Kunci: Gaya Kepemimpinan; Meningkatkan Kinerja; Pondok Pesantren.

\section{ABSTRACT}

This study aims to find out how the style of KH Dede Saepudin's leadership in improving Asatidz's performance at Al-Mua'awanah Islamic Boarding School. This research method uses descriptive method. Data collection techniques in this study are through observation, interviews, and documentation studies. The data analysis is carried out through the interpretation of logic which is related to the context of Da'wah Management. The results 
showed that: First, Communication Style KH. Dede Saepudin in improving the performance of asatidz. Al-Mu'awanah Islamic Boarding School using two communication styles, namely the one-way communication style to the students in the teaching and learning process with the sorogan method, rote deposit and lecture; Second, the type of motivation given by KH. Dede Saepudin to the asatidz is a positive motivation in the form of non-material in the form of social and psychological support in the form of a face to face approach and family deliberations every month; Third, the supervision process of KH. Dede Saepudin on the performance of asatidz is carried out by looking at the presence and improvement of students' learning which will be discussed in family meetings every month.

Keywords: Leadership Style, improve the performance, Islamic boarding school.

\section{PENDAHULUAN}

Masalah kepemimpinan dari dulu hingga sekarang selalu menjadi perhatian yang menarik dan senantiasa memberikan daya pikat yang kuat bagi setiap orang. Mengingat kepemimpinan menduduki posisi sentral dalam suatu organisasi, pemimpinlah yang menentukan perubahan, pembaharuan, perbaikan, dan menjamin kemampuan organisasi untuk terus berprestasi di masa depan.

Suatu organisasi dapat dikatakan akan berhasil atau bahkan gagal sebagian besar ditentukan oleh fungsi kepemimpinan, sehingga tidak berlebihan jika ada ungkapan yang menyatakan pemimpinlah yang bertanggung jawab atas kegagalan pelaksanaan suatu pekerjaan. Ungkapan ini membuktikan betapa kompleknya tugas dan tanggung jawab pemimpin dalam membawa suatu lembaga menuju arah yang lebih baik atau pemimpin adalah ahli strategi yang menetapkan visi dan misi organisasi serta memusatkan perhatian pada cara-cara agar organisasi mencapai tujuan. Dengan memusatkan perhatian pada suatu visi, pemimpin mengoperasikan sumber daya yang ada dengan keragaman karakteristik yaitu meliputi kecakapan teknik (misalnya: mengetahui tentang prosedur tugas dan perlengkapan) dan kecakapan hubungan antar manusia (misalnya: menyadari kebutuhan bawahan dan kemampuan bergaul dengan bawahan).

Pemimpin yang cakap tidak hanya mampu mengusahakan bahwa pekerjaan dapat dilaksanakan dengan baik, produktif, dan efisien, tepat pada waktunya dengan kualitas tinggi, tetapi juga dapat menolong orang-orang dalam organisasi, mengetahui rasa harga diri dan kepuasan dalam bekerja. Para pemimpin yang berhasil seringkali menginspirasi pengikutnya untuk mencapai hasil yang lebih tinggi dengan menunjukkan pada mereka bagaimana pekerjaan mereka dapat memberikan sumbangan yang bermanfaat bagi organisasi yaitu tetap menjaga antara kepentingan organisasi dan kepentingan individu. Pada mulanya kepentingan organisasi atau kelompok dapat mengarahkan dan memotivasi individu untuk bekerjasama dalam kelompok dalam rangka mewujudkan tujuan organisasi. Kepentingan individu bergabung dengan organisasi dengan harapan untuk mendapatkan imbalan dari partisipasinya. 
Imbalan itu bisa berarti kepentingan ekonomi atau berbagai kepentingan psikososial status, harga diri, prestasi dan eksistensi yang berarti sebagaimana individu mendapat imbalan atas peranannya dalam organisasi. Demikian juga organisasi mendapat imbalan dari usahanya menemukan tempat di masyarakat, imbalan itu bisa berupa mungkin ekonomis (keuntungan, pertumbuhan, akses ke berbagai sumber daya) dan atau psikososial (prestise, keabsahan, kekuasaan, dan pengkuan).

Dari survey awal, penulis menemukan bahwa KH. Dede Saepudin sudah termasuk pemimpin yang baik (good leader). Hal ini tercermin dari sikap bawahannya/asatidz yang tetap bersedia mengajar di Pondok pesantren meskipun gaji/upah nya tidak seberapa bahkan tidak di gaji. Hal ini mencerminkan gaya kepemimpinan yang diterapkan KH. Dede Saepudin efektif karena bisa memotivasi asatidz untuk mencapai kinerja terbaiknya dengan bayaran yang terbatas. Melihat tugas penting dari KH. Dede Saepudin yang melakukan pengawasan, maka pemimpin dan gaya kepemimpinannya harus berkembang seiring dengan perkembangan paradigma baru dalam arus globalisasi agar tidak menjadi pemimpin yang ketinggalan jaman.

Yayasan Pondok Pesantren Al-Mu'awanah bermula dari lembaga pendidikan Madarasah dan Majelis Ta'lim yang dirintis sejak tahun 1980 oleh Almarhum H. Ashari, Rd Sanusi dan S. Jaenuddin. Pada tahun 1995 didirikan Pondok Pesantren dibawah pimpinan Almarhum Bapak. S. Jaenuddin. Perkembangan pendidikan Pondok Pesantren Al-Mu'awanah semakin bertambah dengan didirikan Madrasah Diniyah dan TKA-TPA pada tahun 1990.

Selanjutnya Pondok Pesantren Al-Mu'awanah statusnya menjadi sebuah Yayasan yang bernama Yayasan Pondok Pesantren AlMu'awanah (YPPA) yang didirikan pada tanggal 22 September tahun 1999 Akte Notaris Amin Misnedi SH No 03 dengan ketua Yayasan Bapak S. Jaenudin sejak tahun 1999 sampai tahun 2004.

Sepeninggal Bapak S. Jaenuddin, maka jabatan Ketua Yayasan digantikan oleh putra keduanya yaitu KH. Dede Saepudin berdasarkan musyawarah/rapat para pendiri pada Tahun 2004 hingga tahun 2014. Setelah mendapatkan SK. Menhumkam tentang Yayasan, tahun 2015 terjadi penggantian Ketua Yayasan. KH. Dede Saepudin menjadi ketua Dewan Pembina sementara Ketua Yayasan di pegang oleh Bapak Asep Safrudin, S.Pd.

KH. Dede Saepudin dipandang memiliki kemampuan dan keahlian yang harus dimiliki oleh seorang pemimpin, contohnya dalam hal menentukan kebijakan lembaga dan pengambilan keputusan yang tepat. Pemimpin sebagai pelaksana fungsi kepemimpinan sebuah manajemen memiliki tanggung jawab yang besar, dan menjadi faktor penentu dari eksistensi suatu lembaga yang di pimpinnya. Kemudian dalam gaya kepemimpinanya itu KH. Dede Saepudin 
mengutamakan musyawarah dan kerjasama. Kepentingan dengan gaya ini berpola mementingkan kesepakatan bersama. KH. Dede Saepudin dalam lingkungan Pesantren sebagai Pimpinan Yayasan dan sebagai pembina Ekskul Bilal di Madrasah Tsanawiyah, dan Madrasah Aliyah. Kemudian dalam lingkungan masyarakat KH. Dede Saepudin sebagai Ketua MUI Kecamatan Ngamprah.

Perubahan sosial, inovasi, teknologi dan bertambah ketatnya persaingan menghadapkan pada penerapan gaya kepemimpinan pada tantangan yang sulit. Pemimpin dituntut untuk mampu merencanakan, mengkoordinasikan, dan mengorganisasikan sumber daya yang dimiliki agar berdaya guna dan berhasil untuk dapat bertahan dan berkembang di tengah lingkungan yang kompetitif. Dalam lingkungan yang demikian ketatnya kualitas sumber daya manusia sebagai aset yang utama yang merupakan tumpukan bagi kelangsungan hidup lembaga harus dapat dikelola dengan baik oleh pemimpin yang mempunyai kapasitas yang tinggi. Kapasitas KH. Dede Saepudin sebagai pemimpin harus mampu memanage Intelectual Capital dan mengubahnya menjadi produk dan jasa yang berguna dalam meningkatkan efektivitas kinerja asatidz.

Pemberian layanan terhadap lembaga yang konsisten dengan kemampuan human capital yang tinggi, hal ini dapat membuat lembaga dengan efektivitas kinerja yang tinggi dapat mempertahankan kualitas dan prestasi yang unggul dan juga dapat menarik santri mempertahankan kualitas dan prestasi yang unggul dan juga dapat menarik santri baru serta kemungkinan bagi santri di dalamnya yang berpotensial untuk memanfaatkan kualitas inteleqtual capital atau dengan kata lain kinerja asatidz sebagai indikator yang mencerminkan kemampuan untuk kompetesi pada sebuah lembaga yang bersangkutan karena asatidz berfungsi sebagai pedoman dalam membuat perencanaan program pembelajaran, baik program untuk periode tertentu maupun program pembelajaran harian, dan sebagai pedoman untuk implementasi program dalam kegiatan nyata di lapangan.

Dalam hal ini peran asatidz tidak terlepas dari gaya kepemimpinan $\mathrm{KH}$. Dede Saepudin, masih banyak permasalahan yang menyebabkan menurunnya efektivitas kinerja asatidz yang muncul disebabkan kurangnya motivasi yang diberikan, bahkan tidak jarang pada permasalahan tersebut muncul disebabkan gaya komunikasi yang salah karena secara tidak disadari seorang pemimpin dalam memperlakukan atau menerapkan gaya kepemimpinan tersebut dalam rangka menjalankan kepemimpinannya menurut caranya sendiri dan cara-cara yang digunakannya merupakan pencerminan sifat-sifat dasar kepribadian seorang pemimpin walaupun pengertian ini tidak mutlak.

Pada Yayasan Pondok Pesantren Al-Mu'awanah Ngamprah, peneliti menemukan bahwa pendidik (guru/asatidz) sering meninggalkan kelas tanpa memberikan tugas atau guru pengganti dan juga sering tidak masuk kelas tanpa keterangan, sehingga menyebabkan kelas kosong dan tidak terkendali. Di sisi lain 
ada kalanya asatidz selalu hadir sesuai dengan jadwal yang telah diberikan bahkan mengisi kelas tambahan (pengganti). Selain itu, ketidaksiapan asatidz muda dalam menyampaikan materi di kelas menjadi salah satu faktor lemahnya kinerja asatidz. Banyaknya kegiatan para asatidz di masyarakat yang bersamaan dengan waktu mengajar di pondok Pesantren juga menjadi hambatan dalam melaksanakan kegiatan belajar mengajar di pondok pesantren.

Hal ini disebabkan oleh pemberian motivasi yang sering kali berubah dan kurang tepat dalam menganggap bahwa hakekatnya setiap manusia itu sama dan sumber daya manusia didalamnya dapat diperlakukan secara identik. Intinya tidak ada sesuatu yang betul-betul sama dan setiap manusia berbeda secara fisik dan kondisi satu dengan yang lainnya.

Poinnya adalah bahwa pemberian motivasi KH. Dede Saepudin haruslah berbeda kepada setiap asatidz karena perbedaan ini menuntut perhatian agar setiap kerja asatidz dapat menggali potensinya secara penuh sehingga efektivas dapat meningkat dengan memaksimalkan produktivitas kerja meskipun dengan segala keterbatasan Pesantren dalam memberikan imbalan/haji. Produktivitas sebagai salah satu tujuan organisasi adalah bagaimana santri, asatidz, pesantren, dan yayasan pada umumnya mencapai tujuan yang telah ditetapkan. Dengan indikator yang tidak hanya bersifat kuantitatif, tetapi juga bersifat kualitatif. Dengan kata lain produktivitas merupakan fungsi lain efektivitas dan efesiensi. Efektif merupakan ada efeknya (akibat, pengaruh, kesannya), manajer atau mujarab, dapat membawa hasil. Sedangkan efesiensi merupakan aspek yang sangat penting dalam manajemen pesantren karena pesantren dihadapkan pada masalah sumber dana, dan secara langsung berpengaruh terhadap kegiatan manajemen. Jadi dapat disimpulkan bahwa efektif merupakan ukuran yang menggambarkan sejauh mana sasaran yang dapat dicapai sedangkan efesiensi menggambarkan bagaimana sumber-sumber daya yang dikelola secara tepat dan benar. Untuk meningkatkan efesiensi dan efektivitas agar dicapai produktivitas yang tinggi, sumber daya manusia harus diaktifkan, dimotivasi, dipacu, dan dibina untuk mencapai tujuan bersama. Hal ini hanya dapat dilaksanakan apabila perencanaan sumber daya manusia diformulasikan dengan baik melalui proses kepemimpinan yang efektif dengan penerapan sistem penerapan yang dinamis, flexibel dan selalu mengadakan pembaharuan yang tercermin dalam sikap dan gaya kepemimpinan pemimpin dalam berinteraksi dengan asatidz dan santri.

Fenomena diatas menarik untuk diteliti. Paling tidak, menarik untuk diketahui lebih lanjut mengenai gaya komunikasi KH. Dede Saepudin dengan asatidz di Pondok Pesantren Al-Mu'awanah, serta mencoba untuk mengetahui cara meningkatkan motivasi kinerja asatidz di Pondok Pesantren Al-Mu'awanah yang pada dasarnya beberapa asatidz yang berasal dari anggota keluarga dan minim imbalan/gaji. 


\section{LANDASAN TEORITIS}

Miftah Thoha (1983: 255) dalam bukunya yang berjudul Perilaku Organisasi mengemukakan bahwa pemimpin adalah seseorang yang memiliki kemampuan memimpin, artinya memiliki kemampuan untuk mempengaruhi orang lain atau kelompok tanpa mengindahkan bentuk alasannya.

Sejalan dengan gagasan di atas, menurut M. Karyadi (1984: 64) dalam bukunya yang berjudul kepemimpinan menyatakan, Kepemimpinan adalah sebagai seni kemampuan untuk mempengaruhi perilaku manusia dan kemampuan untuk mengendalikan orang-orang dalam organisasi agar supaya mereka sesuai dengan perilaku yang diinginkan oleh pimpinan organisasi

Disamping itu, menurut M Munir (2006: 222) kepemimpinan adalah tindakan dan perilaku pemimpin dalam arti ini digambarkan sebagai serangkaian perilaku seorang da’i yang mengarahkan kegiatan-kegiatan bersama.

Adapun gaya kepemimpinan itu sendiri merupakan suatu pola perilaku yang ditampilkan sebagai pimpinan ketika mencoba mempengaruhi perilaku orang lain. Oleh karena perilaku yang diperlihatkan oleh bawahan pada dasarnya adalah respon bawahan terhadap gaya kepemimpinan yang dilakukan pada mereka. Gaya kepemimpinan lainnya didefinisikan sebagai teknik-teknik gaya kepemimpinan dalamn mempengaruhi bawahannya dalam melaksanakan tugasnya berdasarkan kewenangan dan kekuasaan untuk melaksanakan fungsifungsi manajemen (Suyanto, 2008: 19).

Gaya kepemimpinan menurut pendapat Hasibuan (2007: 170) gaya kepemimpinan dibagi menjadi tiga bagian, yaitu:

Kepemimpinan Otoriter adalah jika kekuasaan atau wewenang, sebagian besar mutlak tetap berada pada pimpinan atau kalau pimpinan itu menganut sistem sentralisasi wewenang. Pengambilan keputusan dan kebijaksanaan hanya ditetapkan sendiri oleh pemimpin, bawahan tidak diikutsertakan untuk memberikan saran, ide, dan pertimbangan dalam proses pengambilan keputusan. Orientasi kepemimpinannya difokuskan hanya untuk peningkatan produktivitas kerja karyawan dengan kurang memperhatikan perasaan dan kesejahteraan bawahan.

Kepemimpinan Partisipatif adalah apabila dalam kepemimpinannya dilakukan dengan cara persuasif, menciptakan kerja sama yang serasi, menumbuhkan loyalitas, dan partisipasi para bawahan. Pemimpin memotivasi bawahan agar merasa ikut memiliki perusahaan. Bawahan harus berpartisipasi memberikan saran, ide, dan pertimbangan dalam proses pengambilan keputusan. Pemimpin dengan gaya partisipatif akan mendorong kemampuan bawahan mengambil keputusan. Dengan demikian, pimpinan akan selalu membina bawahan untuk menerima tanggung jawab yang lebih besar.

Kepemimpinan Delegatif apabila seorang pemimpin mendelegasikan wewenangnya kepada bawahan dengan agak lengkap. Dengan demikian, 
bawahan dapat mengambil keputusan dan kebijaksanaan dengan bebas atau leluasa dalam melaksanakan pekerjaannya. Pemimpin tidak peduli cara bawahan mengambil keputusan dan mengerjakan pekerjaannya, sepenuhnya diserahkan kepada bawahan. Pada prinsipnya pemimpin bersikap menyerahkan dan mengatakan kepada bawahan inilah pekerjaan yang harus saudara kerjakan, saya tidak peduli, terserah saudara bagaimana mengerjakannya asal pekerjaan tersebut bisa diselesaikan dengan baik. Dalam hal ini bawahan dituntut memiliki kematangan dalam pekerjan (kemampuan) dan kematangan psikologis (kemauan). Kematangan pekerjaan dikaitkan dengan kemampuan untuk melakukan sesuatu yang berdasarkan pengetahuan dan keterampilan. Kematangan psikologis dikaitkan dengan kemauan atau motivasi untuk melakukan sesuatu yang erat kaitannya dengan rasa yakin dan keterikatan (Rahmat, 2014: 20).

Kepemimpinan diterapkan di setiap jenis organisasi termasuk lembaga keagamaan semacam pesantren. Berbeda dengan lembaga keagamaan lain, pesantren memiliki ciri khas diantaranya menurut A. Halim (2005: 247) bahwa Pesantren ialah lembaga pendidikan Islam yang mengajarkan ilmu-ilmu keislaman, dipimpin oleh kiyai sebagai pemangku/pemiliki pondok pesantren dan dibantu oleh ustadz/guru yang mengajarkan ilmu-ilmu keislaman kepada santri, melalui metode dan teknik yang khas. Pesantren juga bisa dikatakan sebagai lembaga pendidikan yang disajikan sebagai wadah untuk memperdalam agama dan sekaligus sebagai pusat penyebaran agama. Karena di pesantrenlah agama diajarkan dengan semangat dan di pesantren pulalah ajaran agama disebarkan.

Adapun pengertian dari Pesantren atau Pondok Pesantren berasal dari akar kata cantrik yang merupakan kata benda konkret, kemudian berkembang menjadi kata abstrak yang diimbuhi awalan "pe" dan akhiran "an" pergeseran tertentu kata cantrik berubah menjadi santri dan an berubah menjadi kata en sehingga lahirlah kata Pesantren. Sedangkan Pondok merupakan penyesuaian ucapan kata funduk dalam bahasa arab yang berarti tempat menginap (Amir, 1995: 194).

Dari pengertian di atas dapat dipahami secara bahasa bahwa pondok pesantren merupakan tempat menginap bagi seorang santri. Sedangkan menurut Abd A'la (2006: 9), Pondok Pesantren bukanlah museum purba, tempat bendabenda unik dan kuno disimpan dan dilestarikan ia juga bukan penjara dimana setiap pikiran dan tindakan dikontrol habis-habisan. Akan tetapi Pondok Pesantren adalah "bentuk ruang laboratorium dimana setiap pemikiran dikaji dan diuji ulang". M. Dawam Rahardjo berpandangan bahwa Pondok Pesantren adalah "lembaga yang dapat mewujudkan proses perkembangan sistem pendidikan Nasional". 
Selanjutnya, pengertian kinerja menurut Anwar Prabu (2013: 67) adalah prestasi kerja atau hasil kerja biak kualitas maupun kuantitas yang di capai SDM persatuan waktu dalam melaksanakan tugas kerjanya sesuai dengan tanggung jawab yang diberikan kepadanya. Pengertian Kinerja menurut Amirullah (2015: 231) merupakan seluruh hasli yang di produksi pada fungsi pekerjaan atau aktivitas khusus selama periode khusus. Dari pengertian diatas dapat disimpulkan bahwa kinerja merupakan hasil dari proses pekerjaan tertentu secara terencana pada waktu dan tempat dari karyawan serta organisasi yang bersangkutan.

\section{HASIL DAN PEMBAHASAN}

Penelitian ini dilakukan di Pondok Pesantren Al-Mu'awanah. Rute menuju Pondok Pesantren Al-Mu'awanah ini dapat ditempuh menggunakan kendaraan roda dua maupun roda empat. Lokasi Pondok Pesantren Al-Mu'awanah ini cukup mudah ditemukan karena berada di area perkotaan.

Pondok Pesantren Al-Mu'awanah sebagai tempat belajar para santri dalam menguasai ilmu agama, untuk mencetak kader da’i, menciptakan dan mengembangkan kepribadian muslim yaitu kepribadian yang beriman dan bertaqwa kepada Allah SWT, berakhlak mulia, bermanfaat bagi masyarakat, mandiri, teguh dalam pendirian, serta menyebarkan agama Islam.

KH. Dede Saepudin dalam mengembangkan Pondok Pesantren AlMu'awanah, dengan menerapkan pola kepemimpinan lebih menekankan pada aspek pendidikan dan aspek sosial. Pendidikan agama ditekankan pada santri supaya mendalami tentang ilmu-ilmu agama. Sedangkan aspek sosial diprioritaskan kepada masyarakat, dengan menjalankan kegiatan-kegiatan keagamaan seperti, evaluasi dakwah, mengisi pengajian umum, dan mengajar diniyah. Hal ini disebabkan karena pengetahuan dan pemahaman masyarakat tentang agama masih rendah dan minim. Oleh karena itu diperlukan seorang pemimpin yang mampu merubah masyarakat yang lebih baik, sesuai dengan tuntunan dan ajaran Islam.

Hasil dari penelitian yang dilakukan Pondok Pesantren Al-Mu'awanah, peneliti mendapatkan hasil bahwa Gaya kepemimpinan KH. Dede Saepudin dalam meningkatkan kinerja asatidz di pondok pesantren Al-Mu'awanah, dalam pelaksanaannya di lapangan dapat dikatakan cukup baik, walaupun masih ada kekurangan yang perlu untuk diperhatikan lagi sebagai usaha perbaikan ke depannya nanti.

\section{Gaya Komunikasi KH. Dede Saepudin}

Menurut Soepardi (1988: 15), kepemimpinan didefinisikan sebagai kemampuan untuk menggerakkan, mempengaruhi, memotivasi, mengajak, mengarahkan, 
menasehati, membimbing, menyuruh, memerintah, melarang, dan bahkan menghukum (kalau perlu), serta membina dengan maksud agar manusia sebagai media mnajemen mau bekerja dalam rangka mencapai tujuan administrasi secara efektif dan efisien.

Gaya Komunikasi KH Dede Sepudin tehadap santri di Pondok Pesantren Al-Mu'awanah cenderung lebih bersifat satu arah didalam dalam kegiatan belajar mengajar. Gaya komunikasi satu arah tersebut melalui metode sorogan, ceramah, dan intruksi kegiatan. Tidak jarang KH. Dede Saepudin ikut turun tangan dalam melakukan kegiatan seperti gotong royong sehingga para santri tidak perlu diintruksikan cukup melihat beliau melakukan suatu kegiatan maka otomatis santri akan ikut turut serta melakukan kegiatan tersebut.

Namun pada waktu tertentu beliau tak segan untuk menegur atau memanggil santri yang bermasalah untuk berbicara empat mata khusus dengan beliau. Pendekatan sosial dan psikologis yang beliau lakukan mampu merubah kepribadian santri yang mulanya bermasalah seperti sering pulang tanpa izin atau sering tidak mengikuti kelas pengajian, setelah diberikan nasihat dan motivasi secara face to face ada sedikit perubahan yang berangsur dari santri yang bermasalah. Namun apabila setelah dinasihati dan di peringatkan santri tersebut tidak ada perubahan atau malah tambah parah, maka beliau tidak segan segan memberikan hukuman tegas kepada santri tersebut demi kebaikannya. (Wawancara dengan Muhammad Agyar/ Pengurus santri, 4 April 2018).

KH. Dede Saepudin menjadi sentral dalam aspek komunikasi pada pengelolaan Pondok Pesantren Al-Mu'awanah dilingkungannya. Dalam kehidupan tradisional Pesantren Al-Mu'awanah, komunikasi interpersonal lebih membudaya melalui komunikasi tatap muka yang dianggap sebagai bagian dari salah satu ibadah sunnah yang termotivasi dari orang- orang sholeh terdahulu. Kendati KH. Dede Saepudin, asatidz dan sebagian dari santri menggunakan perangkat komunikasi seperti Smart Phone, Walkie Talkie, mengakses internet, namun kecanggihan perangkat ini lebih bersifat teknis. Tidak dimanfaatkan pada suatu kepentingan komunikasi kelompok dan kebutuhan lain yang bersifat pragmatis.

Komunikasi tatap muka lebih diutamakan disetiap kebutuhan pembahasan suatu masalah dan dalam rangka menjalin silaturahmi. Komunikasi tatap muka dalam Pesantren Al-Mu'awanah bertujuan saling memberikan keteladanan dan rasa kepedulian yang tinggi dalam setiap kesempatan pertemuan secara verbal mau non verbal. Komunikasi tatap muka dijaga secara baik dan berkesinambungan, dimulai dari lingkungan internal melalui interaksi dan komunikasi yang mengedepankan sistem musyawarah atau tukar pendapat yang artinya bertatap muka secara langsung. Hal ini dapat digambarkan dalam suatu skema pola komunikasi inti atau internal Pondok Pesantren Al-Mu'awanah bani 
Amin yang berjalan setiap hari melalui tatap muka, seperti yang sudah digambarkan. (Wawancara dengan Ustadz Asep Abd Rouf /Asatiz Pondok Pesantren Al-Mu'awanah, 4 April 2018).

Meskipun gaya komunikasi KH. Dede Saepudin cenderung formal, namun bahasa yang digunakan dalam proses komunikasi adalah bahasa yang mudah dipahami. Bahasa tersebut adalah bahasa yang sama digunakannya oleh anggota pengurus. Selain itu, kosa kata yang digunakan adalah kosa kata yang umum, mudah dipahami, dan sederhana seperti halnya bahasa yang digunakan oleh seoarang ayah kepada anaknya. Selain secara formal, kyai juga melakukan komunikasi informal. Komunikasi informal yang dilakukan kyai lebih banyak terjadi diluar urusan yang berkaitan langsung dengan organisasi. (Wawancara dengan Ustadz Tantan Hadiannyah/Asatiz Pondok Pesantren Al-Mu'awanah, 4 April 2018).

Koordinasi yang dilakukan para asatidz tampak pada sikap saling memberikan informasi, seperti memberikan tanggapan tentang permasalahan yang terjadi dan saling bekerja sama untuk menyelesaikan tugas. Menurut analisa penulis, koordinasi yang dilakukan KH. Dede Saepudin dengan asatidz telah berjalan sesuai dengan harapan pesantren.

Keterkaitan proses menyelesaian tugas, membuat satu sama lainnya saling berinteraksi. Pengertian koordinasi yang diungkap oleh Usman (2010: 439) dalam bukunya yang berjudul Manajemen, yaitu proses mengintegrasikan (memadukan), menyinkronisasikan, dan menyederhanakan pelaksanaan tugas yang terpisah-pisah secara terus-menerus untuk mencapai tujuan secara efektif dan efesien. Sebagaimana diketahui, manusia mempunyai kebutuhan berafiliasi yaitu ingin menjadi bagian dari suatu kelompok untuk dapat berinteraksi sosial.

Manusia tidak hanya bersosialisasi dalam kerangka tugas/pekerjaan saja, akan tetapi dalam kaitan lingkungan sehari-hari di luar tugas-tugas rutin. Hal ini didukung oleh pernyataan Usman (2010: 439), yang mengatakan bahwa koordinasi adalah bagian penting di antara anggota-anggota atau unit-unit organisasi yang pekerjaannya saling bergantung. Semakin banyak pekerjaan individu-individu atau unit-unit yang berlainan tetapi erat hubugannya, semakin besar pula kemungkinan terjadinya koordinasi. Michael West (1998: 40), di dalam bukunya yang berjudul Kerjasama Kelompok yang Efektif, juga menambahkan bahwa medium penyebaran informasi ditentukan oleh kekayaan informasi itu sendiri. Kekayaan informasi terendah adalah informasi yang penyebarannya dilakukan melalui surat selebaran ataupun surat elektronik. Adapun kekayaan penyebaran informasi yang tergolong menengah adalah bila bila berbentuk pembicaraan telepon, tetapi yang terkaya adalah informasi yang diperoleh lewat pembicaraan langsung atau tatap muka.

Berbagai tujuan dari komunikasi horizontal juga dikemukakan oleh Arni Muhammad (2009: 122) dalam bukunya yang berjudul Komunikasi Organisasi, 
salah satunya adalah dapat menyelesaikan konflik antara anggota, menjamin pemahaman yang sama, serta mengembangkan sokongan interpersonal.

Berdasarkan tujuan di atas maka komunikasi horizontal dapat dilakukan dalam kegiatan rapat/musyawarah. Berdasarkan hasil wawancara yang dilakukan dengan KH. Dede Saepudin, diketahui bahwa kegiatan musyawarah adalah salah satu cara untuk mengetahui segala permasalahan yang ada, sebagai wadah yang menampung pendapat, masukan serta penyampaian solusi yang diberikan Pimpinan Pesantren.

Musyawarah ini berjalan secara demokratis karena setiap orang berhak mengajukan pertanyaan, pendapat, masukan dan kritikan terhadap permasalahan yang terjadi. Biasanya hal yang disampaikan asatidz berupa pendapat tentang seputar kegiatan santri dan permasalahan masyarakat. Menurut Denny (2010: 92), dalam bukunya yang berjudul Communicate to Win, rapat yang baik adalah rapat yang ketika berakhir membuat setiap peserta terinspirasi, bersemangat, kembali antusias, tahu apa yang harus dikerjakan, dan bergairah menghadapi tantangan didepan. Karena itu di dalam proses rapat harus terjadi komunikasi dua arah. Sikap saling menghargai, saling memaafkan dan mau menerima kritikan dengan lapang dada juga diterapkan di Pondok Pesantren Al-Mu'awanah dalam menyikapi permasalahan yang ada. Hal ini didukung oleh pernyataan Denny (2010: 38), yang mengatakan bahwa kemampuan meminta maaf akan membangun suatu hubungan dan membangun gaya komunikasi.

Dapat saya simpulkan dari hasil wawancara diatas bahwa KH. Dede Saepudin melakukan tiga gaya komunikasi yang berbeda, yaitu gaya komunikasi satu arah kepada para santri dalam proses belajar mengajar dengan metode sorogan, setoran hafalan dan ceramah. Adapun gaya komunikasi yang digunakan kepada individu asatidz dan diluar kegiatan belajar mengajar adalah gaya komunikasi antarpribadi yang menghasilkan feedback (Soepardi: 2004: 15).

\section{Proses Pemberian Motivasi}

Pondok Pesantren Al-Mu'awanah ini bertarafkan pesantren komprehensif atau campuran, yaitu pondok pesantren yang sistem pendidikan dan pengajarannya gabungan antara yang tradisional dan yang modern. Artinya didalamnya ditetapkan pendidikan dan pengajarannya kitab kuning dengan metode sorogan, bandongan, wetonan, namun secara regular sistem persekolahan terus di kembangkan (Ghozali, 2002: 46).

Proses pemberian motivasi kepada santri biasanya dilakukan ketika proses kegiatan belajar mengajar. Disamping menyampaikan materi pelajaran, beliau juga sering memberikan nasehat dan motivasi dalam belajar baik dipesantren maupun di sekolah. Bahkan beliau sering memberikan penghargaan kepada para santri yang mendapatkan prestasi dibidang pelajaran ataupun kedisiplinan. 
“... beliau memberikan Al-Qur'an gratis kepada santri diniyah yang sudah tamat Iqra' 6 dan telah lancar bacaan Al-Qur'annya. Beliau memberikan sepaket kitab gratis selama 1 semester kepadapara santri yang mendapatkan juara 1 di pesantren. Pada moment ramadhan juga banyak pemberian penghargaan berupa hadiah tertentu kepada santri yang paling rajin tadarus dan khattam Al-Qur'an, khattam hafalan pelajaran, santri yang tidak pernah absen shalat tarawih dan pengajian pasaran selama bulan Ramadhan. Hal ini cukup membangkitkan semangat para santri dalam berlomba-lomba dalam kebaikan seperti yang diharapkan oleh KH. Dede Saepudin. Terbukti dengan semakin meningkatknya antusias santri dalam menambah hafalan, tidak sering bolos mengaji, dan ikut serta dalam berbagai kegiatan kepesantrenan. Ada juga bentuk dari pemberian motivasi dari pondok pesantren khususnya KH. Dede Saepudin dengan mengadakan kegiatan muhadharah/ Evaluasi Dakwah pada setiap hari ahad ba'da sholat shubuh. Setiap santri sudah mendapatkan gilirannya masing-masing sesuai jadwal yang telah ditetapkan. Acara Mohadhoroh ini dilakukan guna memberikan latihan sekaligus motivasi kepada para santri untuk memberanikan diri berbicara di depan umum atau public speaking. Agar ketika nanti sudah terjung di masyarakat tidak takut dan grogi apabila disuruh bicara di hadapan banyak orang ...”.

Berbeda dengan cara pemberian motivasi terhadap staf guru/ asatidz Pondok pesantren Al-Mu'awanah. Beliau menjelaskan bahwa pemberian motivasi kepada asatidz dan asatidzah tidak berupa reward atau gaji melainkan dukungan sosial dan psikologis melalui musyawarah yang secara intens diadakan dalam waktu tertentu.

“... pemberian motivasi kepada para asatidz biasanya dengan komunikasi face to face pada waktu waktu tertentu, menyampaikan keluhan, kendala bahkan pemberian solusi bagi para asatidz dalam menghadapi masalah baik dalam proses mengajar para santri ataupun permasalahan kepesantrenan ..." (Wawancara dengan Ustadzah Ai Fathonah/Asatizah Pondok Pesantren Al-Mu'awanah, 4 April 2018)

“... saya tidak memberikan penghargaan berupa gaji atau hadiah kepada asatidz dan asatidzah yang mengajar di sini, karena pesantren ini berbasiskan yayasan/sosial dan tidak ada dana khusus untuk menggaji asatidz. Syahriyah (iuran bulanan) dari para santri juga tidak besar, hanya cukup untuk memenuhi kebutuhan sehari-hari santri dan pengembangan pondok pesantren. Sebagian besar asatidz di sini adalah anggota keluarga besar dari Pondok Pesantren Al-Mu'awanah sendiri jadi sadulur-dulur yang mengajar disini, bukan orang lain. Saya hanya mengharapkan keikhlasan dan sesuai kesediaan para astidz dalam mengajar para santri karena mereka sudah tau bahwa ciri-ciri ilmu yang bermanfaat adalah ilmu yang bermanfaat baik untuk diri sendiri maupun untuk di ajarkan kepada orang 
lain meski tidak dibayar sekalipun, karena apabila bukan kita semua yang mengembangkan pondok pesantren ini mau oleh siapa lagi? "(Wawancara dengan KH. Dede Saepudin, 2 April 2018).

Beliau menjelaskan bahwa tidak ada gaji khusus bagi para asatidz, hanya saja mungkin kalau untuk ahsin ilal muhsin (kebaikan untuk yang memberi kebaikan) ada sedikit bayaran namun itu tidak seperti gaji setiap bulan, hanya sekedarnya pada waktu tertentu. Dalam proses pemberian motivasi kepada para asatidz lebih sering dengan face to face terkait permasalahan atau kendala yang ada, ada juga pemberian motivasi melalui pertemuan bulanan keluarga dalam meningkatkan kepercayaan, dan tanggungjawab para astidz terhadap pesantren. Adapun untuk penentuan jadwal mengajar di pesantren itu berdasarkan kesanggupan dan kesediaan dari asatidz itu sendiri, bisanya kapan dan mau mengajar kelas berapa atau mata pelajaran apa itu di kembalikan kepada masingmasing asatidz dan untuk penyesuaian jadwal keseluruhan melalui musyawarah setiap bulannya.

Para asatidz diberikan kewenangan untuk mengelola anggaran uang makan santri mukim yang tinggal di asrama, sehingga sedikitnya ada pemasukan diluar ahsin dari pondok pesantren sendiri. (Wawancara dengan KH. Dede Saepudin, 2 April 2018).

Dari hasil wawancara diatas dapat penulis simpulkan bahwa pemberian motivasi yang dilakukan oleh KH. Dede Saepudin adalah motivasi positif yang berupa non-materiil berupa dukungan sosial dan psikologis berupa pendekatan face to face dan musyawarah keluarga setiap bulannya. Meskipun tidak ada reward berupa gaji kepada para asatidz, namun hal itu tidak menyurutkan niat dan kinerja asatidz karena keikhlasan dan kesediaan asatidz sudah menjadi kewajiban serta pengembangan pondok pesantren sudah menjadi tanggung jawab bersama (Ghozali, 2002: 46).

\section{Proses Pengawasan}

Mangkuprawira dan Hubeis (2007: 153) dalam bukunya Manajemen Mutu Sumber Daya Manusia mengatakan bahwa kinerja adalah hasil dari proses pekerjaan tertentu secara terencana pada waktu dan tempat dari karyawan serta organisasi bersangkutan.

“... meskipun tidak ada gaji khusus untuk asatidz, namun hal ini tidak lantas mengurangi kualitas materi pelajaran dari asatidz disini, karena para asatidz sudah memiliki basic dari pesantren dan sudah terbiasa dalam proses belajar mengajar, maka kualitas pengajaran yang diberikan tidak semata-mata seadanya atau sekenanya saja. Tetap ada kurikulum yang dipegang dan ada standar nilai santri yang harus dicapai guna mempertahankan dan meningkatkan kualitas keilmuan santri ..." 
(Wawancara dengan Ustadzah Ai Fathonah/Asatizah Pondok Pesantren Al-Mu'awanah, 4 April 2018).

Bagi ustadz dan ustadzah ya ng diberi tugas oleh kyai dibidang pendidikan dipondok ini jiga melaksanakan tugasnya dengan baik. Di sini ustadz dan ustadzah dalam menyampaikan pelajaran pada satri kebanyakan menggunakan metode ceramah. Karena megunakan metode ini pelajarannya lebih mudah ditangkap oleh santri-santrinya. Setiap akhir bulan yang tepatnya malam mingguakhir bulan setelah sholat isya, KH. Dede Saepudin mengumpulkan para ustadz dan ustadzahnya untuk mengevaluasi kegiatan apa yang belum terlaksanakan dibulan ini, dan juga merancang kegiatan bulan selanjutnya. Kegiatan yang belum terlaksana di bulan ini akan dimasukkan ke dalam bulan selanjutnya, karena dalam evaluasi ini para ustadz dan ustadzah melaporkan kegiatan-kegiatan yang sudah terlaksana dan maupun belum terlaksana dengan maksimal, serta tentang permasalah yang terjadi kepada beliau sebagai pengasuh pondok.

“... pengawasan kinerja asatidz bisa dilihat dati presentasi kehadiran dan tingkat belajar santri. Apabila presentasi kehadiran asatidz tersebut rendah, jarang masuk kelas, maka saya menggunakan pendekatan individu dengan menanyakan langsung kendala dan hambatan yang menyebabkan rendahnya kehadiran di kelas. Apabila kendalanya karena bentrok jadwal dengan kegiatannya diluar maka akan diadakan perbahan jadwal, dan apabila ada kendala tertentu maka akan dibahas di dalam musyawarah keluarga dan akan diabil keputusan sesuai kesepakatan dan kenyamanan bersama." (Wawancara dengan KH. Dede Saepudin, 2 April 2018).

Tidak ada pelatihan atau arahan khusus kepada para asatidz dalam hal peningkatan kinerja, hanya mungkin penyesuaian terhadap mata pelajaran yang akan diisi, jadwal yang ditetapkan, dan metode yang digunakan untuk proses pembelajaran. Asatidz juga dianjurkan mengenali dan mengetahui kemampuan tiap santri dalam memahami atau menangkap materi pelajaran. Karena ada saja santri yang memliki kendala dalam memahami pelajaran pesantren khususnya pelajaran kitab kuning. Maka, asatidz harus memikirkan metode lain yang bisa digunakan untuk membuat santri tersebut mengerti dan memahami pelajaran tersebut. Pendekatan individu sangat diajurkan dalam hal ini, karena terkadang santri tidak berani mengatakannya di depan umum seperti di kelas. Tapi, ketika bicara empat mata dia baru akan terbuka apa yang menjadi kendala atau hambatannya dalam memahami pelajaran tersebut, apa karena daya ingatnya lemah, atau kurang jelas dalam penerangannya atau seperti apa.

"Dalam proses peningkatan kinerja asatidz yang basicnya adalah sebagai yayasan pasti ada saja kendalanya baik dalam bentuk apapun, tapi saya selaku pimpinan pondok pesantren berusaha untuk bisa menyelesaikan permasalan atau kendala tersebut dengan bermusyawarah dengan para 
asatidz atau yang bersangkutan..." (Wawancara dengan KH. Dede Saepudin, 2 April 2018).

Dapat disimpulkan dari wawancara diatas, proses pengawasan terhadap kinerja asatidz dilakukan dengan cara melihat dari segi kehadiran dan peningkatan belajar santri yang akan dibahas dalam musyawarah keluarga setiap bulannya. Selain pemberian motivasi kepada asatidz, pengawasan dan evaluasi kinerja asatidz juga dibahas dalam musyawarah tersebut (Hubeis, 2007: 153).

\section{PENUTUP}

Berdasarkan temuan dari penelitian yang telah dilaksanakan dan dibahas pada bab-bab sebelumnya, penulis dapat mengambil kesimpulan dari masalah yang penulis bahas yaitu tentang Gaya kepemimpinan KH. Dede Saepudin dalam meningkatkan kinerja asatidz di pondok pesantren Al-Mu'awanah, berdasarkan data yang penulis peroleh maka dapat di ambil kesimpulan sebagai berikut:

Pertama, Gaya Komunikasi KH. Dede Saepudin dalam meningkatkan kinerja asatidz Pondok Pesantren Al-Mu'awanah menggunakan dua gaya komunikasi, yaitu gaya komunikasi satu arah kepada para santri dalam proses belajar mengajar dengan metode sorogan, setoran hafalan dan ceramah. Adapun gaya komunikasi yang digunakan kepada individu asatidz dan diluar kegiatan belajar mengajar adalah gaya komunikasi antarpribadi yang menghasilkan feedback (timbal balik).

Kedua, Jenis pemberian motivasi yang digunakan oleh KH. Dede Saepudin kepada para asatidz adalah motivasi positif yang berupa non-materiil berupa dukungan sosial dan psikologis berupa pendekatan face to face dan musyawarah keluarga setiap bulannya. Meskipun tidak ada reward berupa gaji kepada para asatidz, namun hal itu tidak menyurutkan niat dan kinerja asatidz karena keikhlasan dan kesediaan asatidz sudah menjadi kewajiban serta pengembangan pondok pesantren sudah menjadi tanggung jawab bersama.

Ketiga, Proses pengawasan KH. Dede Saepudin terhadap kinerja asatidz dilakukan dengan cara melihat dari segi kehadiran dan peningkatan belajar santri yang akan dibahas dalam musyawarah keluarga setiap bulannya. Selain pemberian motivasi kepada asatidz, pengawasan dan evaluasi kinerja asatidz juga dibahas dalam musyawarah tersebut.

Keempat, Gaya kepemimpinan KH. Dede Saepudin dalam meningktakan kinerja asatid Pondok Pesantren Al-Mu'awanah adalah gaya kepemimpinan partisipatif yaitu dengan cara menciptakan kerja sama yang serasi dengan asatidz, menumbuhkan loyalitas, dan partisipasi para asatidz. KH. Dede Saepudin memotivasi para asatidz agar merasa ikut memiliki pondok pesantren. Asatidz diperkenankan berpartisipasi memberikan saran, ide, dan pertimbangan dalam proses pengambilan keputusan. KH. Dede Saepudin mendorong kemampuan 
asatidz dalammengambil keputusan. Dengan demikian, KH. Dede Saepudin akan selalu membina para astidz untuk menerima tanggung jawab yang lebih besar. Hal ini sejalan dengan pendapat Hasibuan (2007: 170) tentang Gaya kepemimpinan partisipatif.

Berdasarkan hasil dari pemaparan kesimpulan di atas, maka penulis akan memberikan sedikit saran terkait Gaya kepemimpinan KH. Dede Saepudin dalam meningkatkan kinerja asatidz di pondok pesantren Al-Mu'awanah, yaitu: Pertama, Kepada asatidz agar dapat menumbuhkan motivasi berprestasi yang tinggi dan meningkatkan serta menciptakan sikap asatidz dan peningkatan mutu pendidikan yang baik pula. Kesadaran menumbuhkan motivasi berprestasi, sikap asatidz dan mutu pendidikan tidak saja dipengaruhi oleh faktor luar saja, tetapi yang lebih penting adalah yang berasal dari diri sendiri (motivasi intrinsik) yakni upaya peningkatan kinerja dan profesinya.

Kedua, Motivasi memliki pengaruh terhadap kinerja asatidz, berkenaan dengan motivasi, pihak pondok pesantren hendaknya mampu meningkatkan motivasi kerja asatidz kearah yang lebih baik dengan lebih memprioritaskan pembenahan pada indikatir fisiologis, dimana kebutuhan fisiologis asatidz meliputi, gaji, dan fasilitas yayasan

\section{DAFTAR PUSTAKA}

A'la, A. (2006). Pembaruan Pesantren. Yogyakarta: Pustaka Pesantren.

Amirullah. (2015). Pengantar Manajemen. Jakarta : Mitra Wacana Media.

Feisal, J. A. (1995). Reorentasi Pendidikan Islam Jakarta: GIP.

Halim, A. dkk. (2005). Manajemen Pesantren. Yogyakrta: Pustaka Pesantren.

Hasibuan, M. (2007). Manajemen Sumber Daya Manusia. Cetakan

Karyadi, M. (1984). Kepemimpinan (Leadership). Bandung: Karya Nusantara.

Mangkunegara, A.A. A. P. (2013). Manajemen Sumber Daya Manusia Perusahaan. Bandung : Remaja Rosdakarya.

Mangkuprawira S, A. V. H. (2017). Manajemen Mutu Sumber Daya Manusia, Bogor: Ghalia Indonesia

Munir, M. (2006). Manajemen Dakwah. Jakarta : Prenada Media.

Ponco, W. S. (1999). Analisis dan Perancangan Sistem, Mondial, Jakarta

Soepardi, I. (1988). Dasar - Dasar Manajemen Pendidikan, Jakarta : Depdikbud

Suyanto. (2008). Mengenal Kepemimpinan dan Manajemen keperawatan. Jogjakarta : Mitra \& Cendikia Press.

Thoha, M. (1983). Perilaku Organisasi Konsep Dasar dan Aplikasinya. Jakarta : CV Rajawali.

Rahmat, Y. (2014). Kepemimpinan Transformasional Sebagai Kepemimpinan Dakwah. Ilmu Dakwah: Academic Journal For Homiletic Studies, 10(1), 79-96. 